\title{
Antimicrobial Activity of Silver Nanoparticles against Clinical Biofilms from Patients with and without Dental Caries
}

\author{
Alondra Jaqueline Jiménez-Ramírez, ${ }^{1}$ Rita Elizabeth Martínez-Martínez $\left({ }^{2}{ }^{2}\right.$ \\ José Luis Ayala-Herrera $\mathbb{D}^{3},{ }^{3}$ Erasto Armando Zaragoza-Contreras $\mathbb{D}^{\mathrm{D}}{ }^{4}$ \\ Rubén Abraham Domínguez-Pérez $\mathbb{D},{ }^{5}$ Simón Yobanny Reyes-López $\mathbb{D}^{\circ},{ }^{6}$ \\ Alejandro Donohue-Cornejo $\mathbb{D}^{7}{ }^{7}$ Juan Carlos Cuevas-González ${ }^{\mathbb{D}},{ }^{7}$ Erika L. Silva-Benítez ${ }^{\mathbb{D}}{ }^{8}$ \\ and León Francisco Espinosa-Cristóbal $\left.{ }^{7}\right)^{7}$ \\ ${ }^{1}$ Chemical Biological Department, Institute of Biomedical Sciences, Autonomous University of Juarez City (UACJ), Envolvente del \\ PRONAF and Estocolmo s/n, Ciudad Juárez, Chihuahua 32310, Mexico \\ ${ }^{2}$ Master Program in Advanced Dentistry, Faculty of Dentistry, Autonomous University of San Luis Potosi, Manuel Nava Avenue, \\ Universitary Campus, 78290 San Luis Potosí, Mexico \\ ${ }^{3}$ School of Dentistry, Universidad De La Salle Bajío, Universidad Avenue, Lomas del Campestre, León, Guanajuato 37150, Mexico \\ ${ }^{4}$ Department of Engineering and Materials Chemistry, Centro de Investigación en Materiales Avanzados, \\ S. C., Miguel de Cervantes No.120, Mexico \\ ${ }^{5}$ Laboratory of Multidisciplinary Dental Research, Faculty of Medicine, Autonomous University of Queretaro, Clavel Street, Prados de \\ La Capilla, Santiago de Querétaro 76176, Mexico \\ ${ }^{6}$ Institute of Biomedical Sciences, Autonomous University of Juarez City (UACJ), Envolvente del PRONAF and Estocolmo s/n, \\ Ciudad Juárez, Chihuahua 32310, Mexico \\ ${ }^{7}$ Master Program in Dental Sciences, Stomatology Department, Institute of Biomedical Sciences, Autonomous University of Juarez \\ City (UACJ), Envolvente del PRONAF and Estocolmo s/n, Ciudad Juárez, Chihuahua 32310, Mexico \\ ${ }^{8}$ Faculty of Odontology, Autonomous University of Sinaloa, Josefa Ortiz de Domínguez Street, Universitary Campus, Universitaria, \\ Culiacán, Sinaloa 80010, Mexico
}

Correspondence should be addressed to León Francisco Espinosa-Cristóbal; leohamet@hotmail.com

Received 19 February 2021; Revised 1 June 2021; Accepted 4 June 2021; Published 29 June 2021

Academic Editor: Jianbo Yin

Copyright ( 2021 Alondra Jaqueline Jiménez-Ramírez et al. This is an open access article distributed under the Creative Commons Attribution License, which permits unrestricted use, distribution, and reproduction in any medium, provided the original work is properly cited.

\footnotetext{
Dental caries is an infectious oral disease originated by the presence of different microorganisms from well-defined biofilms. Many treatments for dental caries have been demonstrated to be successful protocols; however, incidence and prevalence remain still high. Although silver nanoparticles (AgNPs) have shown excellent antimicrobial properties, even against different oral bacteria, there is no available scientific information that has evaluated the antimicrobial activity of AgNPs against oral biofilms from subjects with active dental caries. The objective of this research was to evaluate the inhibitory effect of AgNPs in dental biofilms from subjects with and without dental caries. Two sizes of AgNPs were prepared and characterized. Dental plaque samples were collected from 30 subjects with dental caries and 30 subjects with no dental caries. Microbiological analysis was determined by the minimum inhibitory concentration (MIC) of nanoparticles, and the presence and distribution of microbial strains were identified by polymerase chain reaction (PCR) assay. AgNPs had significant antimicrobial effects against all samples of dental plaque; however, the physical properties of AgNPs, as well as specific sociodemographic and clinical conditions from patients, were also associated with bacterial growth inhibition of Ag particles $(p<0.05)$. PCR confirmed the presence of oral bacteria associated with dental caries, such as $S$. mutans and S. sobrinus strains, principally. The AgNPs exhibited great potential to be used as an antimicrobial therapy for the control and prevention of dental caries.
} 


\section{Introduction}

Dental caries is a multifactorial disease that, despite being preventable, has a high incidence in the population; therefore, it is considered a serious public health problem in worldwide $[1,2]$. This disease uses chemical products resulting from bacterial metabolism which causes an imbalance in the process of demineralization-remineralization of tooth tissues, leading to the formation of cavitation [3]. The causative factors of dental caries are diverse; however, dentobacterial plaque is still considered a main etiological agent of this oral disease $[3,4]$. Factors, such as an imbalance in the bacterial populations present in the plaque, the low buffering capacity of saliva, and excessive consumption of fermentable carbohydrates, can cause alterations in the normal balance in the concentrations and distribution of specific microorganism involved in healthy dental plaque, producing pathogenic microbiomes with genetic and metabolic characteristics leading, particularly, to dental caries $[5,6]$. Dental plaque is a complex bacterial community presented as a biofilm that adheres to the tooth surface, the gingival tissues, and the restorative or prosthetic materials $[6,7]$. Thus, the microorganisms present in the dental plaque interact synergistically to constitute a well-organized and complex ecosystem which can become unbalanced due to various environmental changes that can increase the growth of cariogenic bacteria, such as the decrease in $\mathrm{pH}$ and consumption of sucrose [8]. Among the bacteria involved in the pathogenesis of dental caries are Streptococcus mutans (S. mutans), Lactobacillus spp., and Actinomyces spp., considering S. mutans as one of the most microbial strain associated with the beginning and development of this disease $[9,10]$. Currently, there are a wide variety of therapies for the control and prevention of dental caries being the use of flour-based products (bottled and public water, salt for human consumption, toothpaste, mouthwash, dental gel, and others), the most important tools to maintain an adequate oral health $[11,12]$, but also, other diverse products to facilitate the maintenance of oral health (dental varnish, nutritional recommendations, dental materials, and others) have been also designed [13, 14]. Alarmingly, the use of these products have not been successful at all because prevalence and incidence of dental caries, in some poor and underdeveloped countries, remain significantly high $[2,15,16]$. For this reason, other alternative agents with advanced physicochemical properties should be explored, focusing on antimicrobial agents with novel and different properties to be used as an alternative for dental treatments.

In recent years, the use of nanoparticles as antimicrobials is a very new option to prevent and control the development of various infectious diseases [17-20]. Particularly, silver nanoparticles (AgNPs) have demonstrated exceptional bactericidal properties in a wide range of microorganisms, including some oral bacteria [21-23] and, even, better antimicrobial properties than dental antiseptic solutions considered a gold standard in the dental practice [24]. Chemical and physical factors of AgNPs such as an electrical charge on the particle surface, size, shape, risk of particle agglomeration, chemical affinity, free radical formation, free $\mathrm{Ag}^{+}$cations, absorption, presentation, and other characteristics are rele- vant elements that can intervene in the action mechanism of this nanomaterial [25-28]; therefore, the real antimicrobial mechanism is still unclear.

Although there are a lot of reports about the bactericidal effects of AgNPs against different oral bacteria [29-32] or, even, oral microorganisms and biofilms sampled from patients [33], there is no scientific information available that has evaluated the microbial inhibition activity of AgNPs against oral biofilms isolated directly from patients, particularly associated with and without dental caries, using a more representative sampling and molecular assays to confirm the presence and distribution of microbial strains from sampled oral biofilms as well as to explore how sociodemographic and clinical conditions of patients can be statistically associated with the antimicrobial ability of AgNPs. This contribution is aimed at providing deep information about the evaluation of the in vitro inhibitory effects of AgNPs on representative dental plaque samples taken from patients with and without active dental caries, to determine the presence and frequency of microorganism involved in sampled biofilms and to explore the associations of general sociodemographic and clinical conditions and the growth inhibition activity of AgNPs. The results of this work will contribute to determining the capacity of this nanomaterial to control the main etiological factor of dental caries, generating valuable information focused on the possible adaptation and application of AgNPs as a successful alternative in the prevention and control of dental caries.

\section{Materials and Methods}

2.1. Materials and Reagents. Silver nitrate $\left(\mathrm{AgNO}_{3}, \mathrm{CTR}\right.$ Scientific), gallic acid $\left(\mathrm{C}_{7} \mathrm{H}_{6} \mathrm{O}_{5}\right.$, Sigma-Aldrich), sodium hydroxide ( $\mathrm{NaOH}$, Jalmek Scientific ${ }^{\mathrm{TM}}$, Mexico), ammonium hydroxide $\left(\mathrm{NH}_{4} \mathrm{OH}\right.$, Jalmek Scientific ${ }^{\mathrm{TM}}$, Mexico), MüllerHinton (MH, $\mathrm{BD}^{\mathrm{TM}} \mathrm{Difco}^{\mathrm{TM}}$, USA), and $2 \%$ chlorhexidine solutions (CHX, Consepsis ${ }^{\mathrm{TM}}$, Ultradent) were obtained, used, and stored according to the manufacturer's recommendations. All used reagents were of analytical grades.

\subsection{Synthesis and Characterization of Silver Nanoparticles.} The synthesis of silver nanoparticles (AgNPs) was carried out according to the chemical methods described by Espinosa-Cristóbal [33]. In the first method, $0.169 \mathrm{~g}$ of silver nitrate was placed in $100 \mathrm{~mL}$ of deionized water in a beaker, keeping it under magnetic stirring for approximately $2 \mathrm{~min}$. Subsequently, $0.1 \mathrm{~g}$ of gallic acid dissolved in $10 \mathrm{~mL}$ of deionized water was added to the solution. The solution was then immediately adjusted to $\mathrm{pH} 11$, using a $1 \mathrm{M}$ sodium hydroxide solution. In the second synthesis method, the first step of the process described above was repeated, adding silver nitrate to the solution of $0.5 \mathrm{~g}$ of gallic acid dissolved in 10 $\mathrm{mL}$ deionized water; then, it was adjusted to $\mathrm{pH} 10$, using ammonium hydroxide.

Ultraviolet visible (UV-Vis) absorption spectra were obtained for both nanoparticle samples dispersed in water at room temperature with a Cary 100 spectrophotometer (Varian Corp.) using a $10 \mathrm{~mm}$ quartz cell. Also, both solutions were characterized by dynamic light scattering (DLS) 
analysis with a particle analyzer (HORIBA Scientific's ${ }^{\circledR}$, Nano Partica SZ-100, New Jersey, USA) under the following analytical conditions: DPSS laser at a wavelength of $532 \mathrm{~nm}$, scattering angle of $90^{\circ}$, temperature of $25^{\circ} \mathrm{C}$, and viscosity of the dispersion medium of $0.895 \mathrm{mPa} / \mathrm{s}$. In a polystyrene spectrophotometer cell, 3 drops of the AgNPs dispersion were placed and capped with deionized water. The cell was introduced to the particle analyzer, and each sample was analyzed for $120 \mathrm{~s}$ to evaluate the size and particle size distribution. The shape of the AgNPs was determined by transmission electron microscopy (TEM, Phillips CM-200) at an acceleration voltage of $25 \mathrm{kV}$.

2.3. Selection of Patients. A cross-sectional study and a consecutive nonprobabilistic sampling were used for the selection of patients in the Dental Admission Clinic from the Stomatology Department at the Autonomous University of Ciudad Juárez (UACJ). All participating patients signed informed consent before taking the sample according to the ethical guidelines of the Helsinki Declaration (2008). The protocol was approved by the Research Committee of the Biomedical Sciences Institute, Autonomous University of Juarez City. The study groups were as follows: (a) group with dental caries (experimental group) and (b) group without dental caries (control group). Each group was made up of 30 patients with an age range of 18 to 50 years. The presence of dental caries was defined as evident cavitation in the adamantine tissue of at least one lower posterior tooth. The diagnosis of the disease was made by the interns and experts of the Dental Social Services of Dental Surgeon at UACJ.

2.4. Biofilm Sampling. A consecutive and no-probabilistic sampling was used to collect oral biofilms from patients using a sterile wooden toothpick making a mechanical sweep in the cervical area of lower posterior teeth in all included subjects considering subgingival and supragingival levels. The stick containing the bacterial sample was immediately placed in a tube with $5 \mathrm{~mL}$ of $\mathrm{MH}$ and incubated at $37^{\circ} \mathrm{C}$ for $24 \mathrm{~h}$. This procedure was carried on for all microbial samples.

2.5. Initial Bacterial Growth. The optical density (OD) of each sample of dentobacterial plaque was measured by adding $100 \mu \mathrm{L}$ of inoculated bacterial broth in $3 \mathrm{~mL}$ of phosphate buffer contained in a spectrophotometer cell, which was subsequently introduced into a spectrophotometer (Eppendorf ${ }^{\circledR}$, BioPhotometer Plus, Germany) at a wavelength of $550 \mathrm{~nm}$. Next, the bacterial concentration of each of the samples was homogenized at $1.3 \times 10^{8}$ colony forming units per milliliter $(\mathrm{CFU} / \mathrm{mL})$, which was obtained by adding more inoculated broth to the cell with phosphate buffer until reaching an OD of 0.126 at a wavelength of $550 \mathrm{~nm}$ according to the McFarland scale. Finally, the bacterial suspensions were diluted with phosphate buffer until reaching a concentration of $1.3 \times 10^{6} \mathrm{CFU} / \mathrm{mL}$.

2.6. Antibacterial Assay. The antibacterial test was carried out following the methodology previously described [33]. The minimum inhibitory concentration (MIC) of AgNPs was determined by performing serial microdilutions in 96-well plates with the nanoparticles made with both synthesis methods. $200 \mu \mathrm{L}$ of each solution of AgNPs was placed in the first column of the plates in triplicate; then, they were diluted $1: 1$ with $\mathrm{MH}$ broth with $2 \%$ sucrose from the second column. Subsequently, wells were inoculated with $100 \mu \mathrm{L}$ of bacterial suspension $\left(1.3 \times 10^{6} \mathrm{CFU} / \mathrm{mL}\right)$. $\mathrm{CHX}$ at $2 \%$ was used as a gold-standard group under similar conditions to AgNPs. The first and last columns of the plates were used as positive and negative controls, respectively. Finally, the plates were incubated at $37^{\circ} \mathrm{C}$ for $24 \mathrm{~h}$. The MIC was defined as the concentration capable of completely inhibiting bacterial growth, which was determined by visual comparison using differences in turbidity.

\subsection{DNA Extraction and Polymerase Chain Reaction (PCR)} Assay. Six samples of dental plaque from patients with ( $n=3$ subjects) and without ( $n=3$ subjects) dental caries were randomly selected for the identification of specific bacteria. Each sample was inoculated in $\mathrm{MH}$ broth and incubated for $24 \mathrm{~h}$ at $37^{\circ} \mathrm{C}$ and processed according to previous studies [33, 34]. The presence of Streptococcus mutans (S. mutans), Streptococcus sobrinus (S. sobrinus), Streptococcus sanguinis (S. sanguinis), Streptococcus salivarius (S. salivarius), Streptococcus gordonii (S. gordonii), and Streptococcus oralis (S. oralis) was detected by PCR. The presence of $g t f$ genes in the extracted DNA was determined using speciesspecific gtf primers [35, 36]. Positive and negative controls were included in each PCR set. The PCR products were analyzed by electrophoresis using $2 \%$ agarose gel-Tris-acetate EDTA buffer, and a $100 \mathrm{bp}$ DNA ladder marker (New England Biolabs, Beverly, MA, USA) was used as a reference for molecular size. Gels were stained with $0.5 \mu \mathrm{g}$ of ethidium bromide/mL and observed under UV light (E-Gel Imager System with UV Base; Thermo Fisher Scientific, Life Technologies, Waltham, MA, USA).

2.8. Statistical Analysis. The homogeneity of the study groups was examined using the chi-square test. The mean and standard deviation of the patients' age, the OD of the dental plaque samples, and the MICs of each AgNPs solution were calculated. Statistical comparisons of the OD and the MICs of AgNPs between independent groups were made with the Mann-Whitney $U$ statistical test for nonparametric variables. OD, age, and MIC data were also analyzed using Pearson's correlation tests. The significance criterion was $p \leq 0.05$. Statistics were performed with the IBM-SPSS software (SPSS ${ }^{\circledR}$, version 25, Chicago, USA).

\section{Results}

3.1. Characterization of AgNPs. Table 1 reports the physical characteristics of the AgNPs used in this study. The smaller and larger AgNPs demonstrated the nanometric size and narrow particle distribution $(5.2 \pm 1.2$ and $37.4 \pm 3.6 \mathrm{~nm}$, respectively) with spherical and semispherical shapes (Figures 1(a) and 1(c)). Zeta potential showed negative values for both AgNP sizes and electrical charges well defined, limiting the risk of particle agglomeration $(-48.4 \pm 6.9 \mathrm{mV}$ for $5.2 \mathrm{~nm}$ AgNPs and $-52.6 \pm 8.5 \mathrm{mV}$ for $37.4 \mathrm{~nm}$ AgNPs). DLS results indicate that both sizes of nanoparticles had 
TABle 1: Characteristics of AgNPs used in this study.

\begin{tabular}{lcccc}
\hline AgNP & $\begin{array}{c}\text { DLS size } \\
(\mathrm{nm})\end{array}$ & $\begin{array}{c}\text { Initial } \\
\text { concentration } \\
(\mu \mathrm{g} / \mathrm{mL})\end{array}$ & Shape & $\begin{array}{c}\text { Zeta } \\
\text { potential } \\
(\mathrm{mV})\end{array}$ \\
\hline $5.2 \mathrm{~nm}$ & $5.2 \pm 1.2$ & 1070 & Spherical & $-48.4 \pm 6.9$ \\
$37.4 \mathrm{~nm}$ & $37.4 \pm 3.6$ & 1070 & Semispherical & $-52.6 \pm 8.5$
\end{tabular}

DLS: dynamic light scattering. All data are expressed in mean and standard deviation.

appropriate distribution according to the size, identifying both samples as monodisperse systems with single peaks for each sample (Figures 1(b) and 1(d)). UV-Vis spectra of AgNPs show the characteristics surface plasmon of representative Ag nanometric ( $408 \mathrm{~nm}$ for smaller AgNPs and $410 \mathrm{~nm}$ for larger AgNPs); however, secondary absorption bands were also identified ( $284 \mathrm{~nm}$ for smaller AgNPs and $285 \mathrm{~nm}$ for larger AgNPs). This characteristic surface plasmon confirms good stability and dispersion of AgNPs; however, another compound, as residue, can also be present.

3.2. Selection of Patients. The general distribution of patients with and without dental caries is shown in Table 2. In the caries group, the women were more frequent (60\%) than men $(40 \%)$, while in the group without caries, the male subjects were lightly more frequent (53.3\%) compared to female patients (46.7\%). On the other hand, the women patients were older (31.6 to 28.3 years old) compared to men patients (27.8 to 27.5 years old) for caries and noncaries groups, respectively. Although some variations according to gender and age were shown in caries and noncaries groups, no significant differences were presented $(p>0.05)$ indicating homogeneity between the proportion of men and women for both groups.

3.3. Initial Bacterial Growth of Biofilm Samples. Figure 2 shows the comparison of initial bacterial growth between subjects with and without dental caries. The caries group showed higher bacterial growth than the control group (Figure 2(a)) and slight variations between men and women (Figures 2(b) and 2(c)); however, no significant differences were obtained according to the presence of caries and gender $(p>0.05)$. Although bacterial growth was more accelerated in the caries group for men and women (Figure 2(d)), the initial bacterial growth had no statistical significance $(p>0.05)$. These results indicate that the microorganisms involved in dental plaques from patients with and without dental caries presented statistically similar bacterial growth for both male and female subjects.

3.4. Antimicrobial Activity of AgNPs. Table 3 and Figure 3 show the results of the antimicrobial activity of AgNPs. The microorganisms present in dental plaques from patients with caries showed significantly more bacterial growth (120.6 \pm $18.4 \mu \mathrm{g} / \mathrm{mL})$ than those microorganisms included from patients with no dental caries $(77.7 \pm 21.2 \mu \mathrm{g} / \mathrm{mL})(p<0.05)$, determining more significant antimicrobial-resistant levels to the effect of AgNPs for the subjects with caries than patients without caries (Figure 3(a)). For caries and noncaries groups, the smaller AgNPs had significantly better antimicrobial properties $(89.3-51.6 \mu \mathrm{g} / \mathrm{mL})$ compared to larger nanoparticles (152.0-103.7 $\mu \mathrm{g} / \mathrm{mL})$; however, the CHX solution used as a control group demonstrated to have the best bactericidal properties $(34.8-26 \mu \mathrm{g} / \mathrm{mL}$ ) (Figures $3(\mathrm{~b})$ and $3(c))(p<0.05)$. Furthermore, the antimicrobial resistance was higher for the caries group (34.8-152 $\mu \mathrm{g} / \mathrm{mL})$ among all antimicrobial solutions; therefore, the smaller AgNPs (5.2 $\mathrm{nm}$ ) obtained significant differences between the presence of dental caries and MIC values (Figure 3(d)) $(p<0.05)$. In general, both sizes of AgNPs (5.2 and $37.4 \mathrm{~nm}$ ) showed good bacterial growth inhibition for all dental plaque samples taken from patients with and without dental caries (Table 3 ).

Figure 4 illustrates the antimicrobial activity of AgNPs according to gender and the presence of dental caries. According to gender, the bactericidal activity of AgNPs was higher for male subjects $(104.3 \pm 17.6 \mu \mathrm{g} / \mathrm{mL})$ compared to female patients $(94.7 \pm 21.8 \mu \mathrm{g} / \mathrm{mL}$ ) (Figure $4(\mathrm{a})$ ), even for caries and noncaries groups (Figure 4(b)), while dental biofilms from patients with dental caries for men (135.5 \pm $11.4 \mu \mathrm{g} / \mathrm{mL})$ and women $(110.7 \pm 23 \mu \mathrm{g} / \mathrm{mL})$ were more resistant to the antimicrobial activity of AgNPs than dental biofilms from healthy patients $(80.9 \pm 22.4$ and $74.0 \pm 18.8$ $\mu \mathrm{g} / \mathrm{mL}$, respectively) (Figure 4(c)). Although MIC variations were found, principally for biofilms from men subjects and dental caries, no significant differences were determined $(p>0.05)$. These results indicate that the antimicrobial activity of AgNPs is not statistically related to the gender or the presence of dental caries, having similar bacterial inhibition for men and women, even with the presence of dental caries; therefore, there is an evident statistical tendency of gender, principally for men, to be firmly associated to the antimicrobial properties of AgNPs and the microbial behavior of specific oral biofilms, particularly dental caries biofilms (Table 3).

All results are expressed in micrograms per milliliter $(\mu \mathrm{g} / \mathrm{mL})$, mean and standard deviation. For rows, one asterisk indicates significant differences with control group $(p<0.05)$. For columns, similar letters indicate significant differences $(p<0.05)$.

Table 4 reports significant correlations of OD and MIC values according to age, in patients with and without dental caries. Positive correlations were identified for initial bacterial growth for dental caries $(r=0.016)$ and non-dental caries groups $(r=0.179)$, while negative correlations values were identified in both sizes of AgNPs for dental caries (AgNPs $5.2 \mathrm{~nm}, r=-0.162$, and AgNPs $37.4 \mathrm{~nm}, r=-0.265)$ and non-dental caries biofilms (AgNPs $5.2 \mathrm{~nm}, r=-0.250$, and AgNPs $37.4 \mathrm{~nm}, r=-0.241$ ). Although these results could suggest that the bactericidal activity of AgNPs decrease gradually with the age of patients, while the initial bacterial growth increase according to the age, no significant correlations were statistically identified for all groups and variables ( $p>0.05)$, assuming that the age is not related to the natural bacterial growth or the bacterial growth inhibition of AgNPs.

3.5. Bacteria Identification by PCR. To confirm the presence of microorganisms associated with each biofilm group, Table 5 details the distribution of oral Streptococci profiles 


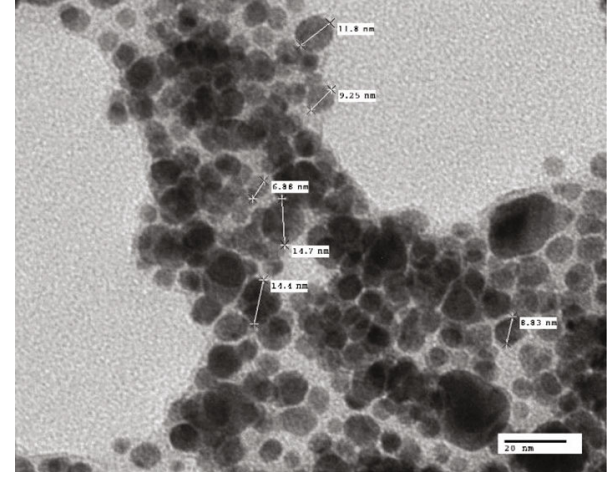

(a)

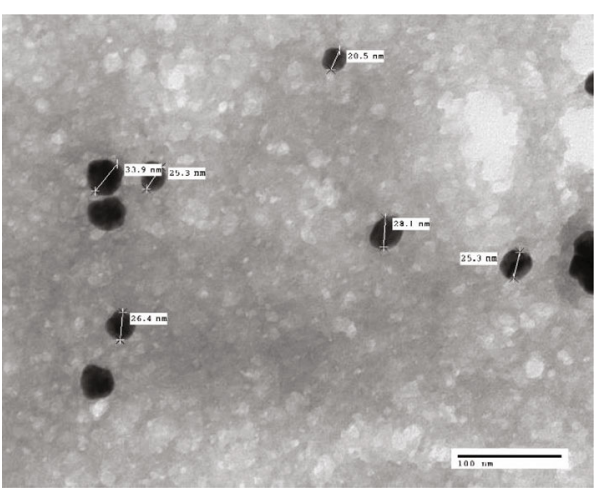

(c)

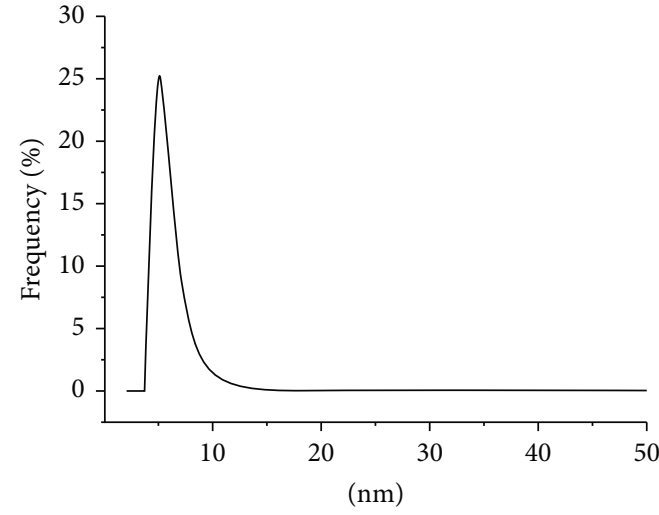

(b)

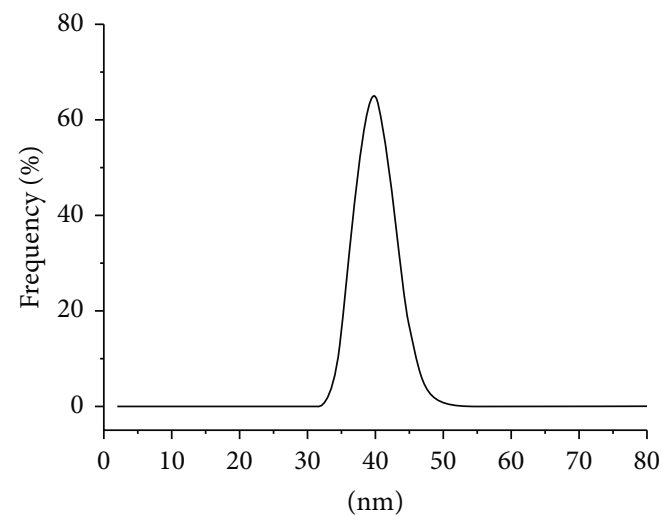

(d)

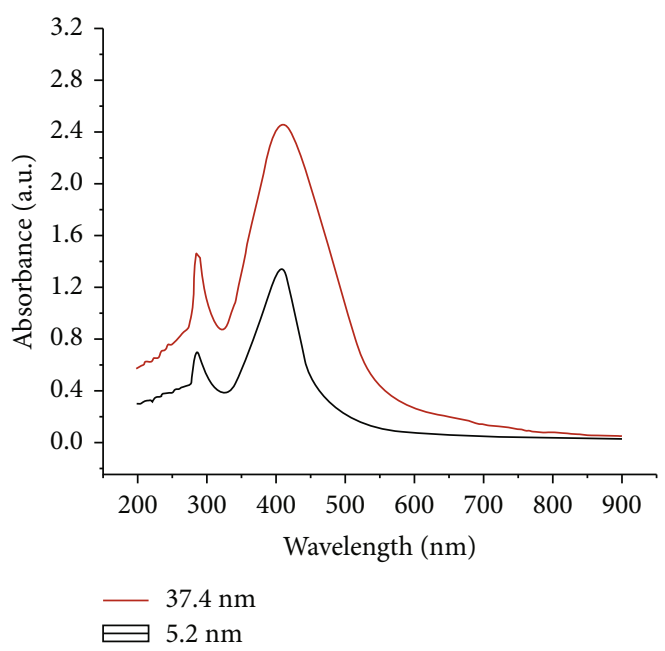

(e)

FIGURE 1: TEM and DLS analysis of AgNPs samples. (a) $5.2 \mathrm{~nm}, 120,000 \mathrm{x}$; (b) DLS for $5.2 \mathrm{~nm}$; (c) $37.4 \mathrm{~nm}$, 40,000x; (d) DLS for 37.4 nm; (e) $\mathrm{UV}-\mathrm{V}$ is analysis.

of representative subjects by PCR. The general distribution was adult-young patients with (47.6 \pm 8.3 years old) and without dental caries ( $50 \pm 7$ years old). The PCR results indicate that the oral Streptococci bacteria were present in almost both groups; however, for the caries group, S. mutans (100\%), S. sobrinus (66.7\%), and S. gordonii (66.7\%) showed the most frequent distribution compared to noncaries subjects $(66.7,33.3$, and $33.3 \%$, respectively), while $S$. sanguinis had a higher frequency of the noncaries group (100\%). Streptococcus salivarius and S. oralis were the most prevalent bacteria in both groups (100\%).

\section{Discussion}

This study determined that the AgNPs used in this work can significantly inhibit the bacterial growth of clinical biofilms 
TABle 2: Distribution of patients with and without dental caries.

\begin{tabular}{lcc}
\hline & $\begin{array}{c}\text { Caries subjects } \\
n=30(\%)\end{array}$ & $\begin{array}{c}\text { Control subjects } \\
n=30(\%)\end{array}$ \\
\hline Gender & & $16(53.3)$ \\
Men & $12(40)$ & $14(46.7)$ \\
Women & $18(60)$ & \\
Age (years) & & $27.5 \pm 8.6$ \\
Men & $27.8 \pm 10.5$ & $28.3 \pm 9.4$ \\
Women & $31.6 \pm 10.8$ & \\
\hline
\end{tabular}

Values from age are expressed in mean and standard deviation; there were no statistical differences between caries and control groups $(p>0.05)$.

strongly associated with and without dental caries. The particle size and the type of biofilm were found as the main factors to promote a high growth inhibition activity of AgNPs. The gender and age of all patients did not show any statistical evidence for correlations with the antimicrobial activity of AgNPs, suggesting that both sizes of AgNPs can favorably inhibit the biofilm growth in any age and gender. As far as we understand, this is the first study that evaluated the antimicrobial levels from different sizes of AgNPs (5.2 \pm 1.2 and $37.4 \pm 3.6 \mathrm{~nm}$ ) against a significant number of dental biofilm samples isolated clinically from patients with $(n=30$ subjects) and without ( $n=30$ subjects) dental caries disease, confirming the presence of oral microorganisms associated with the presence of dental caries. These results create a wider understanding to determine safer and more reliable biomedical therapies focused on regulating the pathogenic bacteria involved in the development of dental caries disease, particularly.

Previous studies reported the synthesis of AgNPs using similar methods like this work, obtaining spherical nanoparticles and sizes in the range $8-20 \mathrm{~nm}[27,37]$. In this work, the synthesis of AgNPs was carried on using silver nitrate with gallic acid as a reductor and stabilizing agent, adjusting each solution to alkaline $\mathrm{pH}$. According to some studies, the gallic acid, in this condition, suffered from the oxidation of its phenolic group which reduces the $\mathrm{Ag}^{+}$ions [18]. The silver atoms, in an oxidation state from cero, start to collide and create a nucleus that grows aggregating more atoms [38]. After the chemical reaction, the gallic acid is transformed into a quinoid compound that is absorbed on the surface of nanoparticles limiting the agglomeration [18]. In this sense, although the synthetic method was similar, small variations may occur. Our results indicate that the semispherical shape presented for the $37.4 \mathrm{~nm}$ sample could be shown due to irregular absorption from the quinoid compound (gallic acid) onto the nanoparticles, promoting irregular or polygonal morphology [18]. Also, the band absorption described by UV-Vis results confirm the presence of nanosized silver (408-410 nm wavelength), which depends on particle size due to the increment in the particle radius associated to the optical properties of AgNPs and their environmental conditions, in this case, the use of gallic acid as reducing agent [39]. On this sense, silver had the most increased surface plasmon resonance band intensity; however, the lowest SPR band intensity could be related to the presence of gallic acid principally [40]. The zeta potential is also considered a relevant property associated with the dispersion of particles. It is known that nanoparticles with zeta potential values between +30 and $-30 \mathrm{mV}$ promote stable suspensions facilitating no agglomerations [41, 42]; moreover, the low $\mathrm{pH}(<7)$ could also be associated with particle agglomerations [42]. Our results demonstrated that the zeta potential of prepared AgNPs presented well-defined and adequate electrical charges for small $(-48.4 \pm 6.9 \mathrm{mV})$ and large $(-52.6 \pm 8.5 \mathrm{mV})$ nanoparticles promoting more stable particles and, consequently, better antimicrobial effects. Besides, various studies have defined AgNPs to be excellent antimicrobial agents [21-23, 31, 43, 44]; however, limited works using AgNPs against clinical biofilms taken directly from patients with dental caries have been reported, in which a low number of microbial strains (1-5 microbial species), no bacteria isolated from patients, or no representative clinical sampling was used $[24,29,33$, 45-47]. In general, these studies have evaluated different sizes of AgNPs on different oral microorganisms (S. mutans, $S$. oralis, Lactobacillus acidophilus, Lactobacillus fermentum, and Candida albicans) obtained from stocks commercially available in an MTCC catalog (Microbial Type Culture Collection (MTCC)) [24], but also, some studies have used only one clinical isolate [45] or microbial stock $[46,48]$ of $S$. mutans strain to create the biofilm, supporting, of all them, the potential use of AgNPs to be an adequate antimicrobial agent for the control of dental caries $[45,47]$ due to bactericidal and bacteriostatic properties [24, 46]. Moreover, scarce scientific reports have used more realistic conditions of oral strains using more representative bacteria sampling from patients with dental caries. One study determined that AgNPs can promote good antimicrobial properties against $S$. mutans strain isolated from patients with dental caries ( $n=30$ patients), obtaining MIC values of $101.98 \mu \mathrm{g} / \mathrm{mL}$ for smaller AgNPs $(8.4 \mathrm{~nm})$ and $145.64 \mu \mathrm{g} / \mathrm{mL}$ for larger particles $(16.1 \mathrm{~nm})$. These authors concluded that clinical strains were consistently more resistant to AgNPs than the reference bacterial sample [29]. Also, authors have tested AgNPs against various microorganisms (A. actinomycetemcomitans, F. nucleatum, S. mitis, S. mutans, and S. sanguinis), obtaining decreased MIC values $(\sim 25 \mu \mathrm{g} / \mathrm{mL})$ for smaller particles $(5$ $\mathrm{nm})$, while in larger nanoparticles $(15 \mathrm{~nm})$, the MIC values were higher $(\sim 50 \mu \mathrm{g} / \mathrm{mL})$; interestingly, $S$. mutans and $S$. mitis strains were the most resistant bacteria to AgNPs [48]. Furthermore, a recent and very similar report to this study evaluated the antimicrobial and substantivity properties of two different sizes of AgNPs (10.2 and $29.3 \mathrm{~nm}$ ) against oral biofilms from sixty-seven young and youngadult subjects ( $23.0 \pm 4.3$ years old); however, only five oral biofilms (male $=2$ and female $=3$ ) from these sixty-seven patients showed the presence of dental caries and periodontal disease ( $n=5$ subjects) confirming the presence of five bacterial strains (S. mutans, S. sobrinus, S. sanguinis, S. oralis, and $S$. gordonii) related to the dental caries disease [33]. These authors reported that both sizes of AgNPs had good antibacterial properties associating the smaller size with better bactericidal properties than larger particles, concluding that AgNPs possess great antimicrobial properties on these clinical samples having potential properties for the control and 


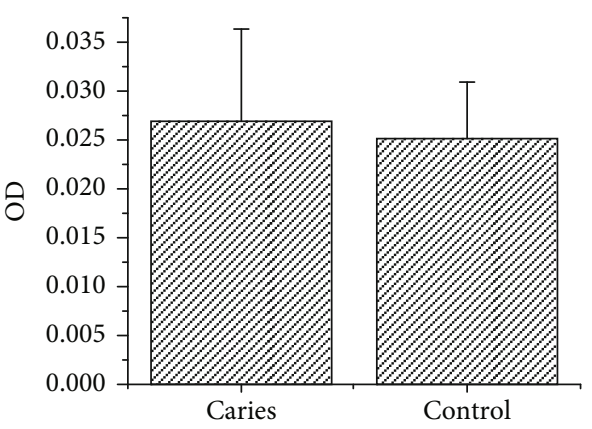

(a)

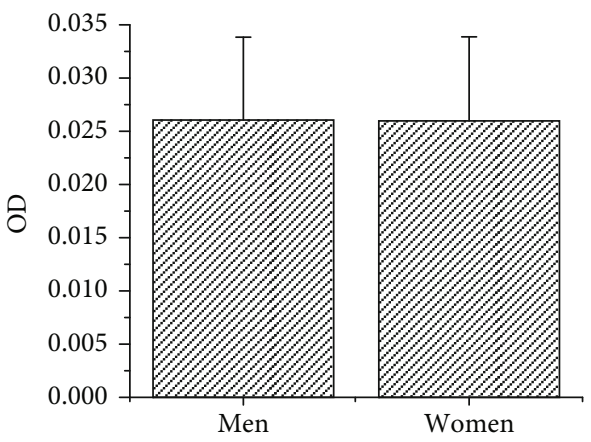

(c)

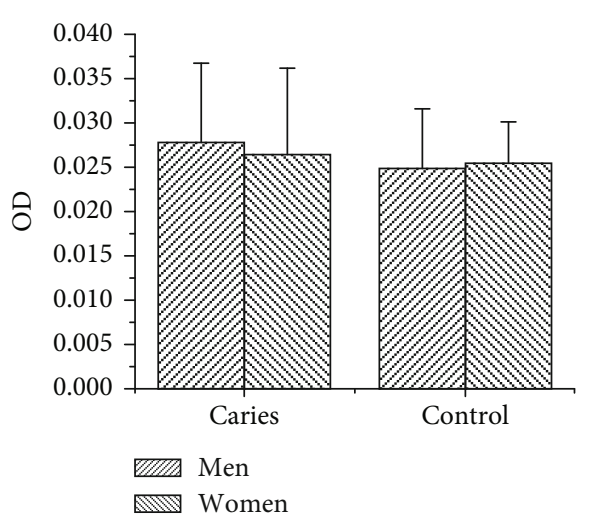

(b)

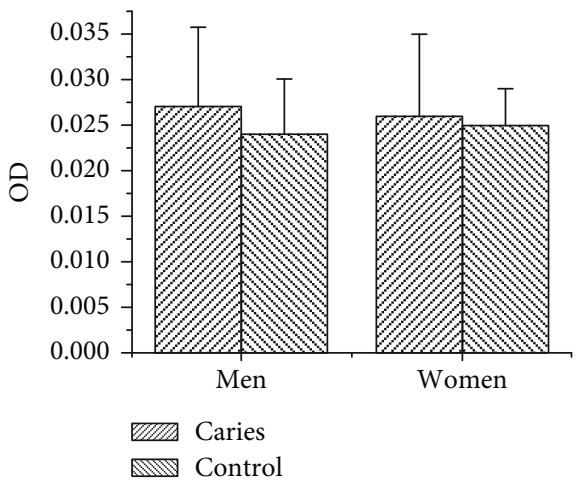

(d)

FIGURE 2: Initial growth of biofilm samples from patients with and without dental caries. All values are expressed in mean and standard deviation. There were no statistical differences $(p>0.05)$.

Table 3: Antimicrobial activity of AgNPs and chlorhexidine on dental plaque from patients with and without dental caries.

\begin{tabular}{lccc}
\hline & Caries $(n=30$ subjects $)$ & Control $(n=30$ subjects $)$ & Total \\
\hline Gender & $135.5 \pm 11.4$ & $80.9 \pm 22.4$ & $104.3 \pm 17.6$ \\
Male & $110.7 \pm 23.0$ & $74.0 \pm 18.8$ & $94.7 \pm 21.8$ \\
$\quad$ Female & & & \\
Antimicrobial treatments & $89.3 \pm 21.7^{*, \mathrm{a}, \mathrm{b}}$ & $51.6 \pm 16.9^{\mathrm{a}, \mathrm{b}}$ & $69.4 \pm 19.3^{\mathrm{a}, \mathrm{b}}$ \\
AgNP 5.2 nm & $152.0 \pm 15.1^{\mathrm{a}, \mathrm{c}}$ & $103.7 \pm 25.6^{\mathrm{a}, \mathrm{c}}$ & $127.9 \pm 20.3^{\mathrm{a}, \mathrm{c}}$ \\
AgNP 37.4 nm & $34.8 \pm 6.9^{\mathrm{b}, \mathrm{c}}$ & $26.0 \pm 0.0^{\mathrm{b}, \mathrm{c}}$ & $30.3 \pm 3.4^{\mathrm{b}, \mathrm{c}}$ \\
CHX & $120.6 \pm 18.4^{*}$ & $77.7 \pm 21.2$ & \\
Total & & \\
\hline
\end{tabular}

All results are expressed in micrograms per milliliter $(\mu \mathrm{g} / \mathrm{mL})$, mean and standard deviation. For rows, one asterisk indicates significant differences with the control group $(p<0.05)$. For columns, similar letters indicate significant differences $(p<0.05)$.

prevention of dental caries and periodontal disease [33]. On the other hand, gender has also been investigated to be associated with drug-resistant bacteria. Authors have reported that oral Streptococci isolated from women had greater resistance to clindamycin than those samples obtained from men; however, no significant differences in multiple antibiotic resistance between both genders were found [49]. Also, investigations have determined that the female gender has shown a higher incidence of cavities related to dental caries, in which it has been speculated that some influencing factors might be hormonal fluctuations, genetic variations, and differences in saliva flow, as well as changes in the buffer and antibacterial capacity during pregnancy [50, 51]. Also, some authors have evaluated drug-resistance levels of oral Streptococcus isolated from patients, determining that the $S$. mutans was one of the most resistant and predominant bacteria with high levels of antimicrobial-resistant to penicillin, amoxicillin, and tetracycline $[49,52]$. Furthermore, it has been also reported that bacteria included in dental biofilms show different characteristics compared to planktonic type because there are interchange processes from genetic elements, inducing increased drug-resistant bacteria [53, 54]. It is known that the microorganisms present in the oral cavity change gradually to the age of the subjects due to particular 

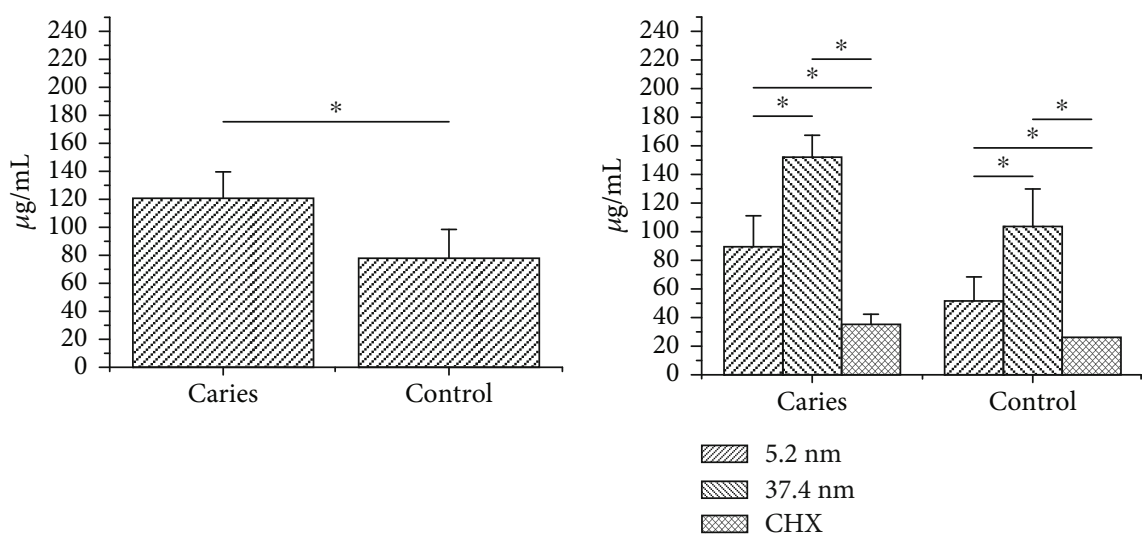

(a)
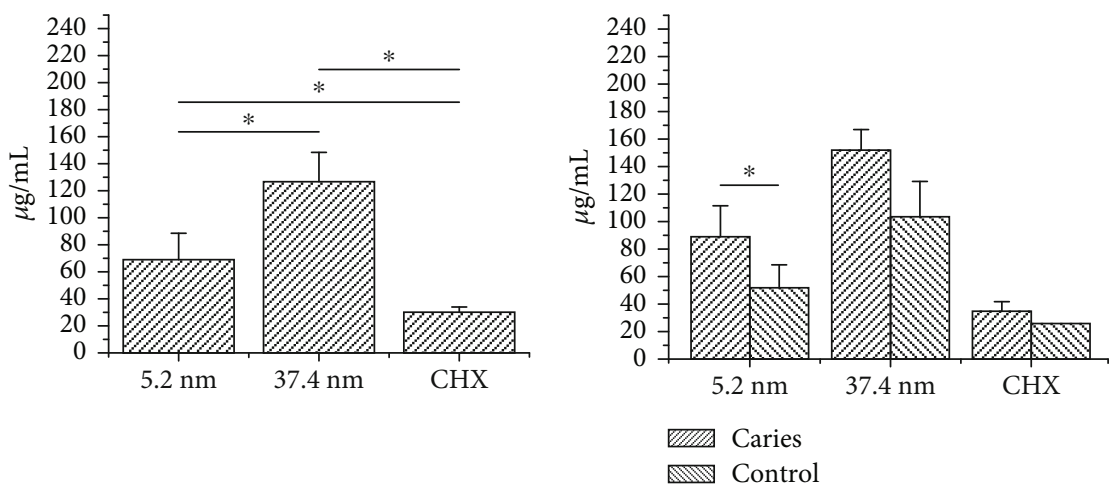

(c)

(d)

FIGURE 3: Antimicrobial activity of AgNPs against biofilms associated with dental caries. All values are expressed in mean and standard deviation. An asterisk indicates $p<0.05$.

factors such as the decrease in saliva production affecting oral environmental conditions [13]; therefore, the microbiome of adults is believed to be stable, except for cases of disease [3]. Our results determined that the initial growth of microorganisms for dental caries and non-dental caries groups, determined by turbidity, was statistically similar $(p>0.05)$, although it was found a higher growth tendency in the dental caries group $(\mathrm{DO}=0.0269 \pm 0.009)$ compared to healthy subjects ( $\mathrm{DO}=0.0251 \pm 0.005)$ (Figure 2). Antimicrobial results showed that both sizes of AgNPs samples (5.2 and $37.4 \mathrm{~nm})$ had adequate antimicrobial activity $(69.4 \pm 19.3$ and $127.9 \pm 20.3 \mu \mathrm{g} / \mathrm{mL}$, respectively) on all clinical biofilm samples, principally for smaller particles; therefore, the CHX group presented the highest antimicrobial properties $(30.3 \pm 3.4 \mu \mathrm{g} / \mathrm{mL})$ (Figure 3$)$. Also, the type of bacterial biofilm associated to dental caries subjects was found to resist considerably the antimicrobial effect of AgNPs (120.6 \pm $18.4 \mu \mathrm{g} / \mathrm{mL})$ than the noncaries group $(77.7 \pm 21.2 \mu \mathrm{g} / \mathrm{mL})$ (Figures 3(a) and 3(d)). Furthermore, significant associations according to gender and the antimicrobial activity of AgNPs were also evaluated (Figure 4). Although no significant associations were identified between gender and the bactericidal activity of AgNPs, this study revealed a very strong statistical tendency, mainly for males, in which men patients showed to have more resistant antimicrobial activity (104.3 \pm $17.6 \mu \mathrm{g} / \mathrm{mL})$ compared to women $(94.7 \pm 21.8 \mu \mathrm{g} / \mathrm{mL})$, but also, male subjects with presence of dental caries were more resistant to the antimicrobial solutions (135.5 \pm $11.4 \mu \mathrm{g} / \mathrm{mL})$ than healthy male patients $(80.9 \pm 22.4 \mu \mathrm{g} / \mathrm{mL})$. Finally, the correlation results suggest that the antimicrobial activity of AgNPs for both biofilm samples (with and without dental caries) was statistically similar for any age $(p>0.05)$, indicating that patients from $\sim 27.5$ to $\sim 31.6$ years old could consistently have acceptable antimicrobial activity of AgNPs (Table 4). These results could suggest that chemical and physical factors of AgNPs such as size, shape, risk of particle agglomeration, chemical affinity, free radical formation, free $\mathrm{Ag}^{+}$cations, absorption, presentation, and other characteristics of AgNPs [21, 22], as well as sociodemographic, clinical, genetic, and, in some cases, hormonal conditions from human subjects [33], could intervene in the action mechanism of this nanomaterial facilitating the adhesion and/or disruption of particles on the membrane of bacterial cell disruption of wall crossing into the cell provoking the adhesion for chemical affinity to thiols, amino, or hydroxyl groups leading cell death, principally [25-28], discarding the action mechanism of AgNPs related to electrostatic interactions from small- and large-particle surfaces negatively charged $(-48.4 \pm 6.9$ and $-52.6 \pm 8.5 \mathrm{mV}$, respectively) with the negatively charged macromolecules (proteins and lipids) included in the cell membrane of bacteria $[22,23]$. It is worth saying that growth media used in this study for all antimicrobial tests were enriched with $2 \%$ sucrose (habitual concentration used in our daily food consumption) which facilitates the 


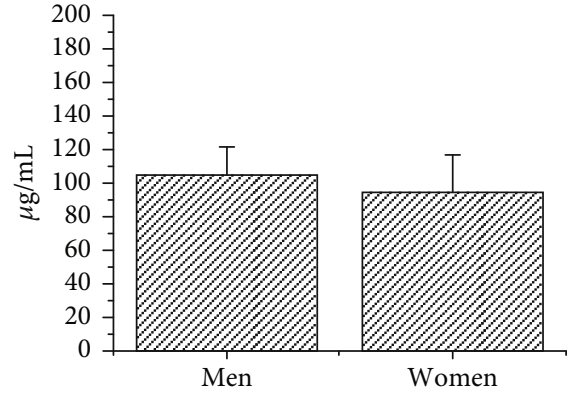

(a)

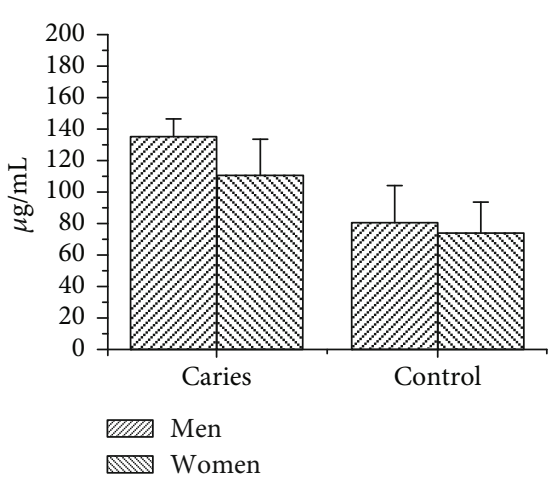

(b)

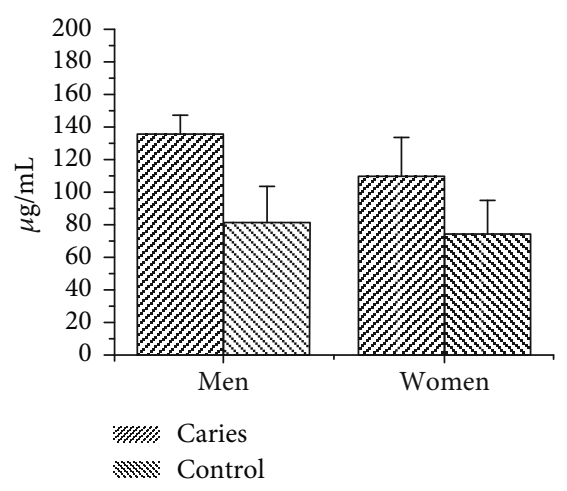

(c)

Figure 4: Antimicrobial activity of AgNP samples against biofilms according to gender and the presence of dental caries. All values are expressed in average and standard deviation. There were no statistical differences $(p>0.05)$.

TABle 4: Pearson's correlation coefficient of OD and MIC values according to age from patients with and without dental caries.

\begin{tabular}{|c|c|c|c|c|}
\hline Variable & $\begin{array}{r}\text { Dental caries } \\
\text { Pearson's correlation coefficient }\end{array}$ & $p$ value & $\begin{array}{c}\text { Control } \\
\text { Pearson's correlation coefficient }\end{array}$ & $p$ value \\
\hline OD & 0.016 & 0.935 & 0.179 & 0.345 \\
\hline AgNP $5.2 \mathrm{~nm}$ & -0.162 & 0.392 & -0.250 & 0.183 \\
\hline AgNP $37.4 \mathrm{~nm}$ & -0.265 & 0.959 & -0.241 & 0.200 \\
\hline
\end{tabular}

There were no statistical correlations $(p>0.05)$.

TABLE 5: Oral Streptococci profiles in representative subjects detected by PCR.

\begin{tabular}{lcc}
\hline & $\begin{array}{c}\text { Noncaries subjects } \\
n=3(\%)\end{array}$ & $\begin{array}{c}\text { Caries subjects } \\
n=3(\%)\end{array}$ \\
\hline $\begin{array}{l}\text { Age (years) } \\
\text { Gender }\end{array}$ & $50 \pm 7$ & $47.6 \pm 8.3$ \\
$\quad$ Male & $1(33.3)$ & $2(66.7)$ \\
$\quad$ Female & $2(66.7)$ & $1(33.3)$ \\
S. mutans & $2(66.7)$ & $3(100)$ \\
S. sobrinus & $1(33.3)$ & $2(66.7)$ \\
S. sanguinis & $3(100)$ & $2(66.7)$ \\
S. salivarius & $3(100)$ & $3(100)$ \\
S. oralis & $3(100)$ & $3(100)$ \\
S. gordonii & $1(33.3)$ & $2(66.7)$ \\
\hline
\end{tabular}

PCR: polymerase chain reaction. Age is expressed in mean and standard deviation.

bacterial growth of microorganisms that metabolizes fermentable carbohydrates [55]. Besides, a biological phenomenon called "quorum sensing" could also intervene in the regulation of gene expressions due to chemical communication with other bacterial species, facilitating adaptation and survival [54]. For S. mutans, studies have determined that this bacterium can develop high resistance to antibiotics, even to AgNPs solutions [2, 56, 57]. Our findings suggest that probably the samples collected from subjects with the presence of dental caries have had the presence of drugresistant microorganisms, including the $S$. mutans, in which higher contents of AgNPs were needed to promote an acceptable growth inhibitory activity, principally in subjects with the presence of dental caries. Surely, this bactericidal effect from nanoparticle samples was attributed to the high rate of oxidation of AgNPs because of $\mathrm{pH}$ variations in the media promoted by the bacteria strains, which facilitates the release of $\mathrm{Ag}^{+}$ions, provoking more damage to the bacterial cells [24]; however, the presence of particular conditions such as gender, type of oral biofilm, and other clinical, diet, oral hygiene, hormonal, genetic, or sociodemographic factors involved in each oral patient could also affect the bacterial growth inhibition of AgNPs [24, 33, 58].

On the other hand, the presence of a wide variety of microorganisms has been reported in dental biofilms from subjects with and without dental caries. One study found that bacterial species such as Actinomyces, Lactobacillus, and S. mutans predominated commonly into the dental plaque associated with dental caries, while bacterial species such as S. parasanguinis, S. mitis, and S. oralis were consistently distributed into dental plaques from healthy subjects $[7,59]$. Also, another study determined the increased presence of $S$. mutans and S. sobrinus in dental plaque from adolescents with dental caries [6]; but also, Corynebacterium and Actinomyces microorganisms have been related to the dental plaque from healthy patients [60]. Another work examined the presence of $S$. mutans in preschool twins with limited dental attention finding no relationship between the presence of the bacteria and the gender of the subject [59]. Authors evaluated the estimated levels of $S$. mutans on two hundred adults from 25 to 35 years old in which the women had predominantly higher bacterial concentrations compared to men [51], while specific microorganisms included in supragingival dental plaque from healthy male and female subjects presented no statistical differences according to 
the distribution of microbiota [61]. Our PCR results confirmed the presence of several oral species associated with dental caries, being the $S$. salivarius and $S$. oralis the most prevalent bacteria for both oral biofilms (100\%). For the dental caries group, the $S$. mutans (100\%) strain was secondarily more frequent even than $S$. gordonii (66.7\%) and $S$. sobrinus (66.7\%) bacteria; while for non-dental caries subjects, the presence of S. mutans, S. sobrinus, and S. gordonii was the least frequent $(66.7,33.3$, and $33.3 \%$, respectively). These results could support the findings previously described in which the presence of specific microbial species, such as $S$. mutans and, probably, S. sobrinus, might develop well-defined microbiological behaviors promoting an increased pathogenicity of dental caries biofilms, at the same time, that other physicochemical conditions of AgNPs as well as clinical singularities from patients would act synergistically to define much better the antimicrobial mechanism of AgNPs [5, 62, 63].

Studies have proposed that the high surface areas, presented in smaller, spherical, and, in some cases, octahedral particles, can promote better surface contact with bacterial cells, improving their ability to penetrate easily the cell membrane of bacteria, reaching their cytoplasm [48, 64, 65]. Thereby, inside the bacterial cell, AgNPs could interact with structures and biomolecules leading to cell death $[21,33]$. One of these interactions is speculated to occur with ribosomes, causing inhibition of signal transduction and protein synthesis; but also, the antimicrobial effect of AgNPs is attributed to its ability to produce $\mathrm{Ag}^{+}$, which has an affinity for sulfhydryl groups present in enzymes, resulting in their deactivation [66]. In this sense, we suggest that a combined antimicrobial mechanism of AgNPs could be related with particular properties of the particles such as smaller sizes, spherical shapes, and well-defined zeta potential; therefore, particular conditions of oral biofilms from patients such as hormonal, sociodemographic, dental, and general health habits and nutritional, clinical, and other relevant factors may intervene, but, at the same time, well-defined mechanisms AgNPs can play an important role in the growth inhibition activity of these nanomaterials.

Additionally, cytotoxic activity is also one of the most important factors to be considered for safe use in medical applications. It has been reported that smaller AgNPs have a high rate of silver ion $\left(\mathrm{Ag}^{+}\right)$dissolution due to larger surface area increasing their bioavailability, distribution, and toxicity compared to larger particles [67]. Also, the $\mathrm{Ag}^{+}$ion releasing has been associated with several factors such as size, shape, concentration, administration routes, coatings, and other physicochemical properties including, particularly, the host susceptibility [68]. However, some authors have demonstrated that the AgNPs could play a relevant role as anti-inflammatory agents due to significant reduction in wound inflammation, modulation of fibrogenic and proinflammatory cytokines, and apoptosis in inflammatory cells [69]. In other words, the toxicity of AgNPs depends on several factors that could include the physiochemical properties of AgNPs (size, shape, zeta potential, coatings, composition, concentration, presentation, distribution, and others), host characteristics (weight, type, age, gender, race, habits, clinical conditions, and other), and the design of therapeutics (dose, administrations routes, and time of exposition) [70].

Although this research offers a better understanding of the antimicrobial activity of AgNPs against oral biofilms associated with dental caries from human subjects and the potential use of this metallic nanomaterial for the control and prevention of dental caries disease, including, probably, the safe use in biomedical applications, it is very recommended to determine a better classification of biofilm samples according to the severity, localization, and extension of dental caries, to apply verbal or written tests to patients to explore their general habits and medical conditions, as well as to analyze and characterize the dental microbiomes using different molecular and microbiological techniques, to define exactly the type and distribution of bacterial species included in each biofilm. Thus, a more detailed therapeutic using AgNPs could be created and focused not only on the antimicrobial efficacy but also on the ability to influence selectively in the microecological regulation of oral biofilms. This, undoubtedly, demands different methodological designs that include other physicochemical evaluations of AgNPs including toxicity/biocompatibility assays through in vitro and in vivo models using a well-defined oral biofilm which is extensively recommended for the safe use in dental therapeutics.

\section{Conclusions}

The AgNPs used in this study were successfully prepared with well-defined physical characteristics. Each system contained homogeneous sizes of AgNPs in acceptable morphology for use as an antimicrobial agent. Both sizes of AgNPs showed an outstanding antimicrobial effect against clinically isolated oral biofilms from patients with and without dental caries. It was also identified that the bactericidal activity of AgNPs was significantly related to particle size, being those with the smallest size which presented a greater effect; moreover, specific types of microbial sample, as the dental caries biofilms, could directly intervene in the antimicrobial activity of AgNPs. Although the AgNPs showed a high potential to be used for the prevention and control of dental caries, more effort, involving other physicochemical features of AgNPs as well as good-defined microbiological conditions of dental microbiomes, particularly from clinical isolates, is highly recommended.

\section{Data Availability}

All data obtained from this study can be found in the research archives of the Master's Program in Dental Sciences of the Autonomous University of Ciudad Juarez and can be requested through the corresponding author.

\section{Conflicts of Interest}

The authors declare that they have no conflicts of interest. 


\section{Acknowledgments}

The authors greatly acknowledge the National Council of Science and Technology (Fondo Mixto-CONACYTGobierno del Estado de Chihuahua 2018-02 (grant number: CHIH-2018-02-01-1167)), Program for Teacher Professional Development (PRODEP), and the Stomatology Department at the Autonomous University of Ciudad Juárez (UACJ) (RIPI2019ICB5) for supporting this work.

\section{References}

[1] R. H. Selwitz, A. I. Ismail, and N. B. Pitts, "Dental caries," The Lancet, vol. 369, no. 9555, pp. 51-59, 2007.

[2] V. P. Mathur and J. K. Dhillon, "Dental caries: a disease which needs attention," The Indian Journal of Pediatrics, vol. 85, no. 3, pp. 202-206, 2018.

[3] N. Takahashi and B. Nyvad, "The role of bacteria in the caries process," Journal of Dental Research, vol. 90, no. 3, pp. 294303, 2011.

[4] I. Struzycka, "The Oral Microbiome in Dental Caries," Polish Journal of Microbiology, vol. 63, no. 2, pp. 127-135, 2014.

[5] N. Takahashi, "Oral microbiome metabolism: from 'who are they?' to 'what are they doing?'," Journal of Dental Research, vol. 94, no. 12, pp. 1628-1637, 2015.

[6] I. Johansson, E. Witkowska, B. Kaveh, P. Lif Holgerson, and A. C. R. Tanner, "The microbiome in populations with a low and high prevalence of caries," Journal of Dental Research, vol. 95, no. 1, pp. 80-86, 2016.

[7] P. M. Corby, J. Lyons-Weiler, W. A. Bretz et al., "Microbial risk indicators of early childhood caries," Journal of Clinical Microbiology, vol. 43, no. 11, pp. 5753-5759, 2005.

[8] P. Marsh, "Dental diseases ? are these examples of ecological catastrophes?," International Journal of Dental Hygiene, vol. 4, no. s1, pp. 3-10, 2006.

[9] J. A. Banas, "Virulence properties of Streptococcus Mutans," Frontiers in Bioscience, vol. 9, no. 1-3, p. 1267, 2004.

[10] R. Rozen, G. Bachrach, and D. Steinberg, "Effect of carbohydrates on fructosyltransferase expression and distribution in _Streptococcus mutans_ GS-5 biofilms," Carbohydrate Research, vol. 339, no. 18, pp. 2883-2888, 2004.

[11] V. C. C. Marinho, D. Hurst, R. Baez, T. M. Marthaler, and Cochrane Oral Health Group, "Salt fluoridation for preventing dental caries," Cochrane Database of Systematic Reviews, no. 5, 2016.

[12] D. M. O'Mullane, R. J. Baez, S. Jones et al., "Fluoride and oral health," Community Dental Health, vol. 33, no. 2, pp. 69-99, 2016.

[13] C. Llena-Puy, "The role of saliva in maintaining oral health and as an aid to diagnosis," Medicina Oral, Patología Oral y Cirugía Bucal, vol. 11, no. 5, pp. E449-E455, 2006.

[14] J. P. Loyola-Rodriguez, F. Garcia-Godoy, and R. Lindquist, "Growth inhibition of glass ionomer cements on mutans Streptococci," Pediatric Dentistry, vol. 16, no. 5, pp. 346-349, 1994.

[15] R. Abed, E. Bernabe, and W. Sabbah, "Family impacts of severe dental caries among children in the United Kingdom," International Journal of Environmental Research and Public Health, vol. 17, no. 1, p. 109, 2020.
[16] I. Nedeljkovic, J. De Munck, A. Vanloy et al., "Secondary caries: prevalence, characteristics, and approach," Clinical Oral Investigations, vol. 24, no. 2, pp. 683-691, 2020.

[17] Y. Andres, L. Giraud, C. Gerente, and P. Le Cloirec, "Antibacterial effects of chitosan powder: mechanisms of action," Environmental Technology, vol. 28, no. 12, pp. 1357-1363, 2007.

[18] W. Wang, Q. Chen, C. Jiang, D. Yang, X. Liu, and S. Xu, “Onestep synthesis of biocompatible gold nanoparticles using gallic acid in the presence of poly-(_N_-vinyl-2-pyrrolidone)," Colloids and Surfaces A: Physicochemical and Engineering Aspects, vol. 301, no. 1-3, pp. 73-79, 2007.

[19] A. Besinis, S. D. Hadi, H. R. Le, C. Tredwin, and R. D. Handy, "Antibacterial activity and biofilm inhibition by surface modified titanium alloy medical implants following application of silver, titanium dioxide and hydroxyapatite nanocoatings," Nanotoxicology, vol. 11, no. 3, pp. 327-338, 2017.

[20] B. Aderibigbe, "Metal-based nanoparticles for the treatment of infectious diseases," Molecules, vol. 22, no. 8, p. 1370, 2017.

[21] K. Halkai, J. Mudda, V. Shivanna, V. Rathod, and R. Halkai, "Antibacterial efficacy of biosynthesized silver nanoparticles against Enterococcus faecalis biofilm: an in vitro study," Contemporary Clinical Dentistry, vol. 9, no. 2, pp. 237-241, 2018.

[22] E. Pazos-Ortiz, J. H. Roque-Ruiz, E. A. Hinojos-Márquez et al., "Dose-dependent antimicrobial activity of silver nanoparticles on polycaprolactone fibers against Gram-positive and Gramnegative bacteria," Journal of Nanomaterials, vol. 2017, 9 pages, 2017.

[23] Á. Martínez-Robles, J. Loyola-Rodríguez, N. Zavala-Alonso et al., "Antimicrobial properties of biofunctionalized silver nanoparticles on clinical isolates of Streptococcus mutans and its serotypes," Nanomaterials, vol. 6, no. 7, p. 136, 2016.

[24] N. P. Panpaliya, P. T. Dahake, Y. J. Kale et al., "In vitro evaluation of antimicrobial property of silver nanoparticles and chlorhexidine against five different oral pathogenic bacteria," The Saudi Dental Journal, vol. 31, no. 1, pp. 76-83, 2019.

[25] S. Prabhu and E. K. Poulose, "Silver nanoparticles: mechanism of antimicrobial action, synthesis, medical applications, and toxicity effects," International Nano Letters, vol. 2, no. 1, article 32, 2012.

[26] I. Sondi and B. Salopek-Sondi, "Silver nanoparticles as antimicrobial agent: a case study on E. coli as a model for Gramnegative bacteria," Journal of Colloid and Interface Science, vol. 275, no. 1, pp. 177-182, 2004.

[27] L. F. Espinosa-Cristóbal, N. López-Ruiz, D. Cabada-Tarín et al., "Antiadherence and antimicrobial properties of silver nanoparticles against Streptococcus mutans on brackets and wires used for orthodontic treatments," Journal of Nanomaterials, vol. 2018, Article ID 9248527, 11 pages, 2018.

[28] J. S. Kim, E. Kuk, K. N. Yu et al., "Antimicrobial effects of silver nanoparticles," Nanomedicine: Nanotechnology, Biology and Medicine, vol. 3, no. 1, pp. 95-101, 2007.

[29] L. F. Espinosa-Cristóbal, G. A. Martínez-Castañón, R. E. Martínez-Martínez et al., "Antibacterial effect of silver nanoparticles against_Streptococcus mutans_" Materials Letters, vol. 63, no. 29, pp. 2603-2606, 2009.

[30] K. Halkai, R. Halkai, J. Mudda, V. Shivanna, and V. Rathod, "Antibiofilm efficacy of biosynthesized silver nanoparticles against endodontic-periodontal pathogens: an in vitro study," Journal of Conservative Dentistry, vol. 21, no. 6, pp. 662-666, 2018. 
[31] C. T. Rodrigues, F. B. de Andrade, L. R. S. M. de Vasconcelos et al., "Antibacterial properties of silver nanoparticles as a root canal irrigant against Enterococcus faecalis biofilm and infected dentinal tubules," International Endodontic Journal, vol. 51, no. 8, pp. 901-911, 2018.

[32] M. Mehta, K. Gauba, and S. B. Bhardwaj, "Nanotechnology: role in dental biofilms," Indian Journal of Dental Research, vol. 20, no. 4, p. 511, 2009.

[33] L. F. Espinosa-Cristóbal, C. Holguín-Meráz, E. A. ZaragozaContreras et al., "Antimicrobial and substantivity properties of silver nanoparticles against oral microbiomes clinically isolated from young and young-adult patients," Journal of Nanomaterials, vol. 2019, 14 pages, 2019.

[34] R. E. Martinez-Martinez, T. Fujiwara, N. Patiño-Marin, T. Hoshino, M. Wilson, and J. P. Loyola-Rodríguez, "Comparison of oral Streptococci biofilm in caries-free and cariesaffected preschool Mexican children," Acta Odontológica Latinoamericana, vol. 25, no. 1, pp. 27-32, 2012.

[35] T. Hoshino, M. Kawaguchi, N. Shimizu, N. Hoshino, T. Ooshima, and T. Fujiwara, "PCR detection and identification of oral streptococci in saliva samples using _GTF_ genes," Diagnostic Microbiology and Infectious Disease, vol. 48, no. 3, pp. 195-199, 2004.

[36] A. Yoshida, N. Suzuki, Y. Nakano, M. Kawada, T. Oho, and T. Koga, "Development of a 5' nuclease-based real-time PCR assay for quantitative detection of cariogenic dental pathogens Streptococcus mutans and Streptococcus sobrinus," Journal of Clinical Microbiology, vol. 41, no. 9, pp. 4438-4441, 2003.

[37] J. F. Hernández-Sierra, F. Ruiz, D. C. Cruz Pena et al., "The antimicrobial sensitivity of_Streptococcus mutans_to nanoparticles of silver, zinc oxide, and gold," Nanomedicine: Nanotechnology, Biology and Medicine, vol. 4, no. 3, pp. 237-240, 2008.

[38] A. K. Mittal, Y. Chisti, and U. C. Banerjee, "Synthesis of metallic nanoparticles using plant extracts," Biotechnology Advances, vol. 31, no. 2, pp. 346-356, 2013.

[39] Y. A. Krutyakov, A. A. Kudrinskiy, A. Y. Olenin, and G. V. Lisichkin, "Synthesis and properties of silver nanoparticles: advances and prospects," Russian Chemical Reviews, vol. 77, no. 3, pp. 233-257, 2008.

[40] J. López-Esparza, L. F. Espinosa-Cristóbal, A. Donohue-Cornejo, and S. Y. Reyes-López, "Antimicrobial activity of silver nanoparticles in polycaprolactone nanofibers against Grampositive and Gram-negative bacteria," Industrial \& Engineering Chemistry Research, vol. 55, no. 49, pp. 12532-12538, 2016.

[41] T. Q. Tuan, N. V. Son, H. T. K. Dung et al., "Preparation and properties of silver nanoparticles loaded in activated carbon for biological and environmental applications," Journal of Hazardous Materials, vol. 192, no. 3, pp. 1321-1329, 2011.

[42] G. Vanitha, K. Rajavel, G. Boopathy, V. Veeravazhuthi, and P. Neelamegam, "Physiochemical charge stabilization of silver nanoparticles and its antibacterial applications," Chemical Physics Letters, vol. 669, pp. 71-79, 2017.

[43] S. K. Kailasa, T.-J. Park, J. V. Rohit, and J. R. Koduru, “Antimicrobial activity of silver nanoparticles," in Nanoparticles in Pharmacotherapy, pp. 461-484, Elsevier, 2019.

[44] J. R. Koduru, S. K. Kailasa, J. R. Bhamore, K.-H. Kim, T. Dutta, and K. Vellingiri, "Phytochemical-assisted synthetic approaches for silver nanoparticles antimicrobial applications: a review," Advances in Colloid and Interface Science, vol. 256, pp. 326339, 2018.
[45] M. A. Pérez-Díaz, L. Boegli, G. James et al., "Silver nanoparticles with antimicrobial activities against_Streptococcus mutans_ and their cytotoxic effect," Materials Science and Engineering: C, vol. 55, pp. 360-366, 2015.

[46] I. X. Yin, O. Y. Yu, I. S. Zhao et al., "Developing biocompatible silver nanoparticles using epigallocatechin gallate for dental use," Archives of Oral Biology, vol. 102, pp. 106-112, 2019.

[47] A. Besinis, T. De Peralta, and R. D. Handy, "Inhibition of biofilm formation and antibacterial properties of a silver nano-coating on human dentine," Nanotoxicology, vol. 8, pp. 745-754, 2013.

[48] Z. Lu, K. Rong, J. Li, H. Yang, and R. Chen, "Size-dependent antibacterial activities of silver nanoparticles against oral anaerobic pathogenic bacteria," Journal of Materials Science: Materials in Medicine, vol. 24, no. 6, pp. 14651471, 2013.

[49] J. P. Loyola-Rodriguez, M. E. Ponce-Diaz, A. Loyola-Leyva et al., "Determination and identification of antibioticresistant oral streptococci isolated from active dental infections in adults," Acta Odontologica Scandinavica, vol. 76, no. 4, pp. 229-235, 2018.

[50] M. Ferraro and A. R. Vieira, "Explaining gender differences in caries: a multifactorial approach to a multifactorial disease," International Journal of Dentistry, vol. 2010, Article ID 649643, 5 pages, 2010.

[51] P. Pannu, R. Gambhir, and A. Sujlana, "Correlation between the salivary Streptococcus mutans levels and dental caries experience in adult population of Chandigarh, India," European Journal of Dentistry, vol. 7, no. 2, pp. 191-195, 2013.

[52] K. Yadav, S. Prakash, N. Yadav, and R. Sah, "Multi-drug resistance of bacterial isolates among dental caries patients," Janaki Medical College Journal of Medical Science, vol. 3, no. 1, pp. 37-44, 2016.

[53] N. Høiby, T. Bjarnsholt, M. Givskov, S. Molin, and O. Ciofu, "Antibiotic resistance of bacterial biofilms," International Journal of Antimicrobial Agents, vol. 35, no. 4, pp. 322-332, 2010.

[54] C. Moser, H. T. Pedersen, C. J. Lerche et al., "Biofilms and Host Response - Helpful or Harmful,” vol. 125, no. 4, pp. 320-338, 2017.

[55] X.-L. Tian, G. Dong, T. Liu et al., "MecA protein acts as a negative regulator of genetic competence in Streptococcus mutans," Journal of Bacteriology, vol. 195, no. 22, pp. 51965206, 2013.

[56] A. Kaur, D. Goyal, and R. Kumar, "Surfactant mediated interaction of vancomycin with silver nanoparticles," Applied Surface Science, vol. 449, pp. 23-30, 2018.

[57] G. Kaur, S. Rajesh, and S. A. Princy, "Plausible drug targets in the streptococcus mutans quorum sensing pathways to combat dental biofilms and associated risks," Indian Journal of Microbiology, vol. 55, no. 4, pp. 349-356, 2015.

[58] A. Y. Grün, J. Meier, G. Metreveli, G. E. Schaumann, and W. Manz, "Sublethal concentrations of silver nanoparticles affect the mechanical stability of biofilms," Environmental Science and Pollution Research, vol. 23, no. 23, pp. 24277-24288, 2016.

[59] P. M. A. Corby, W. A. Bretz, T. C. Hart, M. M. Filho, B. Oliveira, and M. Vanyukov, "Mutans streptococci in preschool twins," Archives of Oral Biology, vol. 50, no. 3, pp. 347-351, 2005. 
[60] B. J. F. Keijser, E. Zaura, S. M. Huse et al., "Pyrosequencing analysis of the oral microflora of healthy adults," Journal of Dental Research, vol. 87, no. 11, pp. 1016-1020, 2008.

[61] P. J. Zawadzki, K. Perkowski, M. Padzik et al., "Examination of oral microbiota diversity in adults and older adults as an approach to prevent spread of risk factors for human infections," BioMed Research International, vol. 2017, Article ID 8106491, 7 pages, 2017.

[62] M. F. Şuhani, G. Băciuț, M. Băciuț, R. Şuhani, and S. Bran, "Current perspectives regarding the application and incorporation of silver nanoparticles into dental biomaterials," Medicine and Pharmacy Reports, vol. 91, no. 3, pp. 274-279, 2018.

[63] A. P. V. Colombo and A. C. R. Tanner, "The role of bacterial biofilms in dental caries and periodontal and peri-implant diseases: a historical perspective," Journal of Dental Research, vol. 98, no. 4, pp. 373-385, 2019.

[64] A. A. Ashkarran, S. Estakhri, M. R. H. Nezhad, and S. Eshghi, "Controlling the geometry of silver nanostructures for biological applications," Physics Procedia, vol. 40, pp. 76-83, 2013.

[65] A. Alshareef, K. Laird, and R. B. M. Cross, "Shape-dependent antibacterial activity of silver nanoparticles on Escherichia coli and Enterococcus faecium bacterium," Applied Surface Science, vol. 424, pp. 310-315, 2017.

[66] Y. Qing, L. Cheng, R. Li et al., "Potential antibacterial mechanism of silver nanoparticles and the optimization of orthopedic implants by advanced modification technologies," International Journal of Nanomedicine, vol. 13, pp. 33113327, 2018.

[67] C. Recordati, M. De Maglie, S. Bianchessi et al., "Tissue distribution and acute toxicity of silver after single intravenous administration in mice: nano-specific and size-dependent effects," Particle and Fibre Toxicology, vol. 13, no. 1, article 12, 2015.

[68] M. A. Raza, Z. Kanwal, A. Rauf, A. N. Sabri, S. Riaz, and S. Naseem, "Size- and shape-dependent antibacterial studies of silver nanoparticles synthesized by wet chemical routes," Nanomaterials, vol. 6, no. 4, p. 74, 2016.

[69] A. Hebeish, M. H. El-Rafie, M. A. EL-Sheikh, A. A. Seleem, and M. E. El-Naggar, "Antimicrobial wound dressing and antiinflammatory efficacy of silver nanoparticles," International Journal of Biological Macromolecules, vol. 65, pp. 509-515, 2014.

[70] Z. Ferdous and A. Nemmar, "Health Impact of Silver Nanoparticles: a Review of the Biodistribution and Toxicity Following Various Routes of Exposure," International Journal of Molecular Sciences, vol. 21, no. 7, p. 2375, 2020. 